\title{
Stakeholder Management of Kawasan Konservasi Mangrove dan Bekantan in Tarakan City
}

\author{
Rifky Edo Herlangga, Sambas Basuni*
}

\begin{abstract}
Department of Forest Resource Conservation and Ecotourism, Faculty of Forestry, IPB University (Bogor Agricultural University), Dramaga Campus, Bogor, Indonesia 16680
\end{abstract}

\begin{abstract}
Kawasan Konservasi Mangrove dan Bekantan (KKMB) is a protected area that is managed by Tarakan City Government for mangrove and proboscis monkey conservation. KKMB has a few stakeholders involved in the area. In order to create collaborative management, there must be conducted a stakeholder analysis and management. The research aimed to give stakeholder management recommendations for KKMB. Research data was collected through interviews and questionnaires. This research was also conducted to compare two methods in stakeholder analysis, Reed et al. method and Driscoll and Starik method. The result shows that Driscoll and Starik method is more objective to be used for measuring the stakeholder priority. PT Pertamina EP had to be the first priority in stakeholder management because it has great power, urgency, and legitimacy towards KKMB. In order to improve the relationship between stakeholders in KKMB there must be applied a practical strategy. This strategy strives for optimizing the area advantages for all stakeholders and also fulfill the stakeholders' needs for the area, which are facility maintenance, area sustainability improvement, and optimization of tourism activity.
\end{abstract}

Keywords: categorization, relationship, priority, strategy

*Corresponding author, email: sambas.basuni@gmail.com,tel.+62-251-8621947

\section{Introduction}

Kawasan Konservasi Mangrove dan Bekantan (KKMB) is a protected mangrove forest that is under the Decree of Tarakan City Mayor Number 591/HKV/257/2001 about the utilization of the mangrove forest and the Decree of Local Regulation Number 04 in 2002 about the prohibition and monitoring of mangrove forest in Tarakan. KKMB is managed as a natural tourism object with the main attraction of mangrove forest and bekantan (proboscis monkey), which is an endemic fauna of Borneo. KKMB is managed by the city government in order to conserve the wildlife, mangrove ecosystem, also as a tourism object. In the future, the development of KKMB will be directed not only as a tourism object but also developed to be an education place for the study of mangrove and bekantan.

Based on the Decree of the Tarakan City Mayor Number $552 /$ HK-IX/741/2010 KKMB is managed by Dinas Pariwisata Kota Tarakan (Tarakan Government Tourism Agency), after previously managed by Dinas Lingkungan Hidup Kota Tarakan (Tarakan Government Environmental Agency). The regulation is giving a right for Dinas Pariwisata Kota Tarakan to coordinate a work unit of local agency or institution that has a relationship with KKMB.
Dinas Pariwisata Kota Tarakan also has the right to assign the third party to manage the finances of KKMB with the permission of Tarakan Mayor.

Based on Wiharyanto (2007), the development of ecotourism in KKMB tends to be obstructed due to the coordination system that is not going so well. A good relationship between the stakeholders is needed to develop ecotourism in KKMB (Wiharyanto, 2007). Stakeholder management is an effort to choose an effective strategy to coordinate the stakeholder involvement in a project to achieve the objectives of the project. In the beginning, the stakeholder management will identify the actor that has a relationship with KKMB, then in the final stages of the analysis will be produced the future management strategy of the area. Therefore, it is necessary to conduct a study of stakeholder management in KKMB.

\section{Methods}

This research was conducted in Tarakan City, North Kalimantan, Indonesia. Data were collected by a semistructured interview where the informant guided by the researcher in the interview discussion. Data were collected by the snowball method through the interview, observation, 
and document analysis (Bungin, 2010). The snowball method began from Dinas Pariwisata Kota Tarakan as the key informant of the research and then will be rolling to another stakeholder based on who is mentioned by Dinas Pariwisata. Interviews were conducted to key informants, heads of the institutions, and the community that was related to KKMB. Then the interview was developed and following the information from the key informant. Information deepening is considered complete when there is a saturation of information from key informants characterized by the repetition of the same information (Syahputra et al., 2018).

Stakeholder data of KKMB were obtained from various literature, reports, and other documents related to this research. Closed-ended questions were used in the research questionnaire given to the verified stakeholder. The questionnaires that were collected from each stakeholder were compared based on the scoring that has been made.

Based on Manullang (2018), the stakeholder profile is used to identify the mandate of each stakeholder, the impact (positive or negative) that is accepted by the relation with $\mathrm{KKMB}$, the relationship between stakeholders with KKMB, also the stakeholder interest and influence for KKMB. The stakeholder role is the contribution from the stakeholder for $\mathrm{KKMB}$. The source of conflict in the management of a region because each actor seeks to harness the power he has to get his interests, and it can differentiate the interests and influence among stakeholders (Febriyano, 2014). One stakeholder could have more than one role (Manullang, 2018), depending on its interest with KKMB.

Stakeholder statuses were determined to understand their involvement with KKMB. The status category, which was examined, was stakeholder roles as a primary or secondary actor (Clarkson, 1995), strategic or moral actor, and the stakeholder involvement as a directly involved or indirectly involved actor (Manullang, 2018). A primary stakeholder is the one which without its continuing participation in the corporation or area (KKMB) cannot survive as a going concern; meanwhile, a secondary stakeholder is not essential for its survival (Clarkson, 1995). A strategic stakeholder is the one who influences the area. The moral stakeholders are those who influenced by the area. Stakeholder position is the perception of stakeholders on their involvement with KKMB. Stakeholders' position was determined to understand the stakeholder perception for KKMB. The stakeholder position was classified as three perceptions, which are actors that obtain advantages from KKMB (friend), actors that obtain disadvantages from KKMB (foe), and actors that do not get advantage or disadvantage from KKMB (neutral).

The relationship between stakeholders and KKMB was analyzed by Actor-Centred Power (ACP) that was developed by Krott et al. (2014). ACP is used to analyze how an actor that has the power to alter the behavior of other actors (potentate) interacts with another actor that its behavior has been altered (subordinate) without recognizing subordinates' will. Every ACP actor plays in different relations. In a relationship, an actor could have a double role: as a potentate and as a subordinate, depending on the specific issue. Krott et al. (2014) developed three elements of power, which are coercion, incentive or disincentive, and dominant information. Coercion is an ability to alter behavior by force, incentive is an ability to alter behavior by giving an advantage, disincentive is an ability to alter behavior by giving disadvantage, and dominant information is an ability to alter behavior by unverified information to another actor. The dominant information element was not used in this research. This is because the data collection of this element will take a long period and requires very close proximity to the respondent interviewed.

Stakeholder priority was determined by two methods, which are Reed et al. method and Driscoll and Starik method. The Reed et al. method was conducted by comparing stakeholders' interests and influence power towards KKMB. The maximum score that could be achieved in the scoring of each attribute component was 5. Interest refers to the needs of stakeholders in order to achieve its outputs and goals (Reed et al., 2009). The measurement of stakeholder interest used the attribute of stakeholder involvement, advantages that were achieved, and the role of a stakeholder. The measurement of influence was conducted by the amount of power owned by each stakeholder. The elements of power measured were condign power, compensatory power, and conditioning power (Galbraith, 1983). Stakeholders are mapped into an interest-influence matrix, which consists of four quadrants (Reed et al., 2009). The quadrants represent the category of stakeholders that are grouped into a key player, context setter, subject, and crowd.

In Driscoll and Starik's method, a stakeholder is determined by calculating its power, legitimacy, urgency, and proximity towards KKMB. The stakeholder powers measured were condign power, compensatory power, and conditioning power. Measurement of stakeholder urgency was conducted by identifying the weight of stakeholder urgency towards KKMB. The stakeholder legitimacies measured were entity legitimacy, claim legitimacy, and behavior legitimacy from each stakeholder. There are three types of stakeholder proximity, which are spatial, formal, and social proximity (Manullang, 2018).

Mitchell et al. (1997) states that stakeholder attributes are categorized as dormant, discretionary, demanding, dominant, dependent, dangerous, and definitive stakeholders (Driscoll \& Starik, 2004). Manullang (2018) adds the attribute of marginal and non-priority stakeholders to this list. In the stakeholder categorization phase, the proximity was not used, because in this phase, every stakeholder considered have proximity with KKMB. The maximum score that could be achieved for each stakeholder attribute was 5. Stakeholders that do not have any of the attributes of power, legitimacy, urgency, and proximity get the score 0 , stakeholders that have the attribute score in the range of 11.67 get the score 1 , stakeholders that have the attribute score in the range of 1.68-3.34 get the score 2, and stakeholders that have the attribute score in the range of 3.35-5 get the score 3. stakeholder priority is determined by using Equation [1] (Manullang, 2018). 
Considering that stakeholder power is weighted three, stakeholder urgency is weighted two, and one for stakeholder legitimacy and proximity, based on the understanding that the score given for stakeholder power must be higher than urgency, and score that is given for stakeholder urgency must be higher than stakeholder legitimacy and proximity (Parent $\&$ Deephouse, 2007).

\section{Results and Discussion}

KKMB stakeholders Stakeholders' data that have been verified by Dinas Pariwisata Kota Tarakan showed that 13 stakeholders have a relationship with KKMB (Table 1). Those stakeholders consisted of five government agencies, one educational institution, two state-owned enterprises, four private companies, and one community group. Stakeholders' statuses are the characteristics of an institution (Manullang, 2018) towards their involvement with KKMB.

Badan Perencanaan Pembangunan Daerah (BAPPEDA) Kota Tarakan (Development Planning Agency of Tarakan City) is a governmental institution that has a role in coordinating all of the city development plan, BAPPEDA involved in the development of KKMB. Dinas Pariwisata Kota Tarakan (Tarakan Government Tourism Agency) is a governmental institution that coordinates all of the city tourism activity, this institution is the principal manager of KKMB. Dinas Lingkungan Hidup Kota Tarakan (Tarakan Government Environmental Agency) is a governmental institution that has a role in coordinating all of the city environmental issues, this institution is the main manager of KKMB in 2008 until 2010. Kecamatan Tarakan Barat is one of four district offices in Tarakan that has the mandate to serve administrative matters of West Tarakan community. This institution is the principal manager of KKMB from 2002 until 2007. Kelurahan Karang Rejo is a government institution that has the mandate to serve administrative matter of Karang Rejo community, KKMB is located in Kelurahan Karang Rejo administrative area. Universitas
Borneo Tarakan is the only national university in Tarakan. This institution has the mandate to develop the tropical sea resources and the national border area, Universitas Borneo used KKMB as an educational facility and for scientific research.

PT Perusahaan Listrik Negara (PLN) Tarakan is a stateowned enterprise that has the mandate for supplying the electrical energy for Tarakan. This institution helps to provide supporting facilities in KKMB. PT Pertamina EP is a state-owned enterprise that has the mandate for supplying the national needs for oil and gas. This institution helps to provide supporting facilities in KKMB. PT Gusher is a private enterprise in the form of the traditional and modern market located beside KKMB area. This institution helps to provide supporting facilities in KKMB. PT Mustika Minanusa Aurora is a private enterprise in the form of seafood processing located beside KKMB area. This institution helps to provide supporting facilities in KKMB. PT Sabindo Raya Gemilang is a private enterprise in the form of seafood processing located beside KKMB area. This institution helps to provide supporting facilities in KKMB. PT Medco EP is a private enterprise in the form of oil and gas resources provider. This institution helps to provide supporting facilities in KKMB. Crab fisher is community actors that illegally entered KKMB at night to catch crabs.

KKMB stakeholders relationship From a total of 13 stakeholders, as many as eight of stakeholders have relations with other actors, both mutually beneficial relationships between the parties and relationship that harms one party. Stakeholders that are only related to KKMB and not related to other actors are Kecamatan Tarakan Barat, Kelurahan Karang Rejo, and PT PLN. There are coercive and incentive or disincentive relations that occurred in KKMB stakeholder interaction, those relations come from various types of power sources (Table 2).

Interaction of Dinas Pariwisata and Dinas Lingkungan

Table 1 Kawasan Konservasi Mangrove dan Bekantan stakeholders

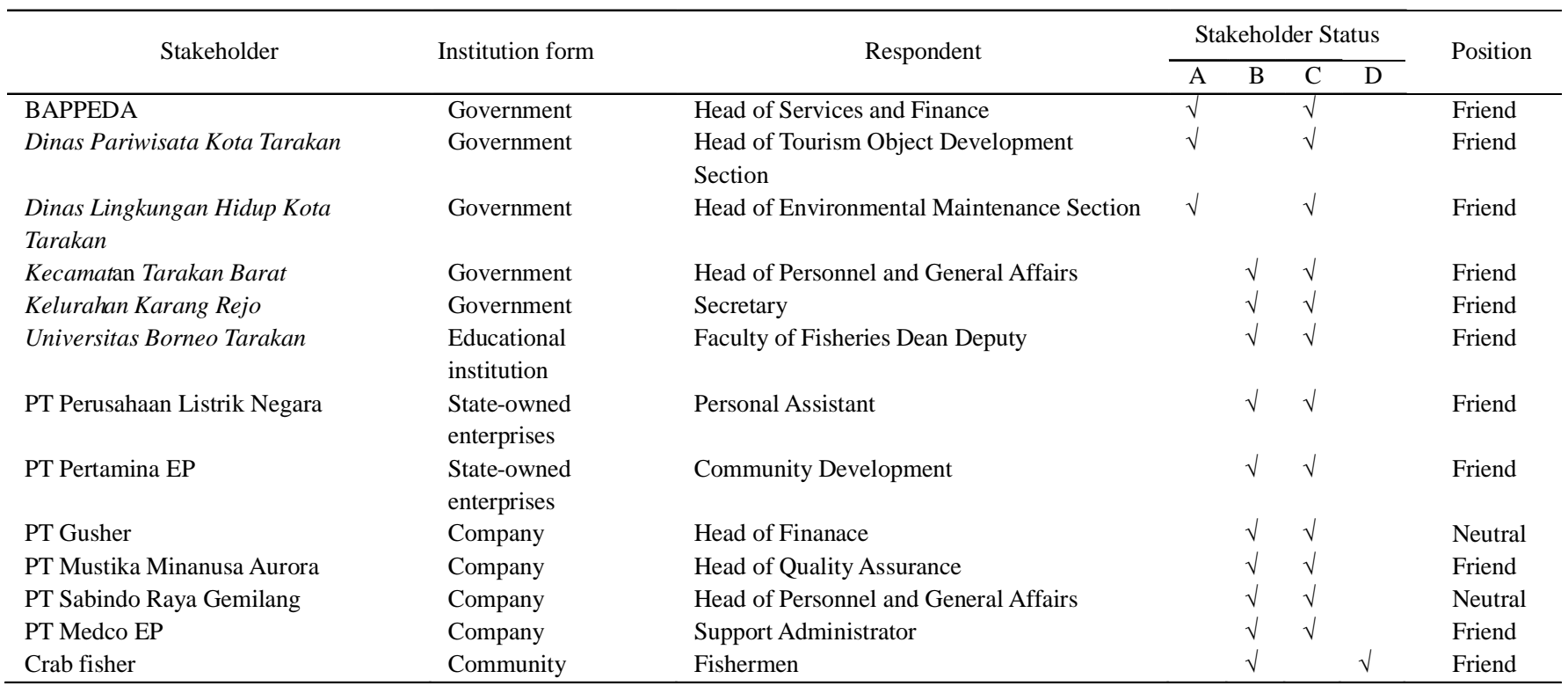


Table 2 KKMB stakeholders relationship element

\begin{tabular}{|c|c|c|c|c|c|}
\hline \multicolumn{2}{|c|}{ Stakeholder } & \multicolumn{3}{|c|}{ Element } & \multirow{2}{*}{$\begin{array}{c}\text { Source of } \\
\text { Power }\end{array}$} \\
\hline Potentate & Subordinate & $\mathrm{A}$ & $\mathrm{B}$ & $\mathrm{C}$ & \\
\hline BAPPEDA & Dinas Lingkungan Hidup & & $\sqrt{ }$ & & Regulation \\
\hline BAPPEDA & Dinas Pariwisata & & $\sqrt{ }$ & & Regulation \\
\hline Dinas Pariwisata & Dinas Lingkungan Hidup & & & $\sqrt{ }$ & Regulation \\
\hline Dinas Pariwisata & Crab fisher & $\sqrt{ }$ & & & Regulation \\
\hline Dinas Lingkungan Hidup & Crab fisher & $\sqrt{ }$ & & & Regulation \\
\hline PT Pertamina EP & Dinas Lingkungan Hidup & & $\sqrt{ }$ & & Financial \\
\hline PT Pertamina EP & Dinas Pariwisata & & $\sqrt{ }$ & & Financial \\
\hline PT Mustika Minanusa Aurora & Dinas Lingkungan Hidup & & $\sqrt{ }$ & & Financial \\
\hline PT Mustika Minanusa Aurora & Dinas Pariwisata & & $\sqrt{ }$ & & Financial \\
\hline PT Gusher & Dinas Pariwisata & & $\sqrt{ }$ & & Financial \\
\hline PT Medco EP & Dinas Lingkungan Hidup & & $\sqrt{ }$ & & Financial \\
\hline PT Medco EP & Dinas Pariwisata & & $\sqrt{ }$ & & Financial \\
\hline PT Sabindo Raya Gemilang & Dinas Lingkungan Hidup & & $\sqrt{ }$ & & Financial \\
\hline PT Sabindo Raya Gemilang & Dinas Pariwisata & & $\sqrt{ }$ & & Financial \\
\hline Crab fisher & Dinas Lingkungan Hidup & $\sqrt{ }$ & & & Physical \\
\hline Crab fisher & Dinas Pariwisata & $\sqrt{ }$ & & & Physical \\
\hline PT Gusher & Dinas Lingkungan Hidup & & & $\sqrt{ }$ & Physical \\
\hline Universitas Borneo & PT Mustika Minanusa Aurora & & $\sqrt{ }$ & & Science \\
\hline
\end{tabular}

Information: Element $\mathrm{A}=$ Coercion, $\mathrm{B}=$ Incentive, $\mathrm{C}=$ Disincentive

Hidup as a potentate towards the crab fisher (subordinate) was KKMB regulation establishment of the prohibition fishing activity in the area, the interaction that happened was administrative coercive. Crab fisher, in this interaction, also played the role of a potentate that performed a coercive action by trespassing the area without the permission of Dinas Pariwisata and Dinas Lingkungan Hidup that in this case played the role as a subordinate. The interaction between Dinas Pariwisata, Dinas Lingkungan Hidup, and Crab fisher proved the statement of Krott et al. (2014), which states that in one relation, an actor could both play as a potentate and also as a subordinate stakeholder, depending on the specific issue.

Incentive interaction happened in the relation between the state-owned enterprise and private company stakeholders towards Dinas Lingkungan Hidup and Dinas Pariwisata for the area management activity. The incentives given by those stakeholders were the help of area management funding and facility maintenance of KKMB. Another incentive interaction happened was the relation between Universitas Borneo and PT Mustika. In this relation Universitas Borneo helped to provide the scientific data that PT Mustika needs to implement conservation activity in KKMB. Disincentive relation happened in the interaction between PT Gusher and Dinas Lingkungan Hidup. In this interaction PT Gusher pollutes the KKMB with the waste from their traditional markets, so it disrupted the ecological function of KKMB. Another disincentive relation happened in the interaction between Dinas Pariwisata as the principal manager of the area towards Dinas Lingkungan Hidup. In this interaction, Dinas Pariwisata did not use its authority to coordinate with Dinas Lingkungan Hidup, so Dinas Lingkungan Hidup cannot run its mandate to maintain the ecological function of KKMB because they were not involved in the area management.

\section{Stakeholder categorization}

(1) Reed et al. method

The Reed et al. method was conducted by analyzing the level of interest and influence of stakeholders towards KKMB. Interest is the amount of stakeholder need towards the area, meanwhile influence is the amount of stakeholder power to have an impact towards KKMB. Stakeholder interests were measured with the stakeholder involvement, the benefit that stakeholder got, and the role it plays towards KKMB. The analysis result showed the different levels of interest and influence among stakeholders.

Every stakeholder in KKMB has a different influence level towards the area. Galbraith (1983) states that measuring the influence of a stakeholder can be done by using the stakeholder instrument of power, which is coercive, utilitarian, and normative power. Coercive power (condign power) is a stakeholder power to give a punishment or sanction to another actor. This influence could be done by giving the administrative sanction, physical sanction, financial sanction, and legal sanction. Utilitarian power (compensatory power) is an ability of a stakeholder to give compensation to another actor through remuneration, activity assistance, land giving, and award-giving. Normative power (conditioning power) is an ability to manipulate or forming opinion and information, norm and cultural power, educational power, and also propaganda power.

The most significant level of interest and influence was owned by PT Pertamina EP and Kecamatan Tarakan Barat. It was because PT Pertamina EP involved in the activity of natural resource protection, community development, tourism services, and also management activity of KKMB. Kecamatan Tarakan Barat has a high level of influence towards KKMB because this 
institution has an ability to give administrative and legal sanction, this institution could also help KKMB by giving financial support, facility, and activity assistance. PT Gusher also has a high level of interest and influence towards KKMB because it has a role in the provision of tourism facility, financial support, and also natural resource protection in KKMB. The score of stakeholder interest and influence are mapped in the influenceinterest matrix (Figure 1). The influence-interest matrix was divided into four quadrants, which are crowd, subject, context setter, and key player quadrant (Reed et al., 2009).

According to the influence-interest matrix, the institutions that were grouped as key players are PT Pertamina EP, PT Gusher, Dinas Pariwisata, BAPPEDA, and PT Medco because they were stakeholders with high interest and influence towards KKMB. It is usual for most natural-based management that the legal company or agency becomes the most important stakeholder (Maguire et al., 2012). Stakeholders that were grouped as context setters are Kecamatan Tarakan Barat and PT Sabindo because of their low interest but great influence towards KKMB. Stakeholders that were grouped as subjects because of their high interest and low influence towards KKMB are Kelurahan Karang Rejo and Universitas Borneo. PT Mustika Minanusa Aurora, Dinas Lingkungan Hidup, and crab fisher were categorized as crowds because of their low interest and influence towards KKMB. Those categories showed that only five stakeholders categorized as the key players in KKMB. This condition could be improved by managing the stakeholders so that every actor could be more involved in its relation with KKMB.
(2) Driscoll and Starik method

Stakeholder categorization on this method was based on the analysis of the power, urgency, legitimacy, and proximity attribute of stakeholders. The attribute of power consisted of coercive, utilitarian, and normative power. Urgency is the level of sensitivity of an interest measured by the aspect of time and the existence of the project or area (KKMB). According to Manullang (2018), stakeholder legitimacy is interpreted as the suitability of stakeholder entity, claim, and behavior towards scientific rules, applicable legal rules, and human rights.

The Driscoll and Stariks' method is based on stakeholder attributes of power, urgency, and legitimacy that have been developed by Mitchell et al. (1997) and also added by the attribute of proximity to understand the relations between each stakeholder towards the project or area. The proximity attribute was measured by the component spatial proximity, formal proximity, and social proximity. Before measuring the attribute score, there must be conducted the stakeholder categorization without using the proximity attribute because of every institution must have proximity towards KKMB. This categorization aims to find out if there is a dangerous stakeholder on the list. Besides that, this category was also used as consideration in determining stakeholder priority.

According to stakeholder categorization, there were four categories of KKMB stakeholders, which were definitive, discretionary, demanding, and non-priority stakeholders. Definitive stakeholders are those institutions who have the power, urgency, and legitimacy towards KKMB. The definitive stakeholders of KKMB were BAPPEDA, Dinas Pariwisata, Dinas Lingkungan Hidup, Kecamatan Tarakan Barat, Universitas Borneo,

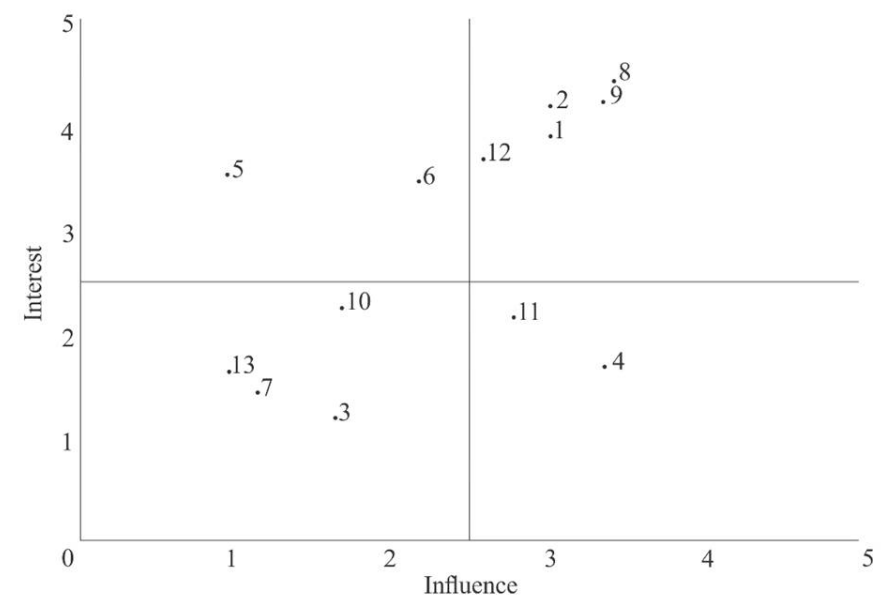

Information:

1. BAPPEDA

2. Dinas Pariwisata

3. Dinas Lingkungan Hidup

4. Kecamatan Tarakan Barat
5. Kelurahan Karangn Rejo

6. Universitas Borneo Tarakan

7. PT PLN
8. PT Pertamina EP

9. PT Gusher

10. PT Mustika
11. PT Sabindo

12. PT Medco

13. Crab fisher

Figure 1 Interest-influence matrix. 
Table 3 KKMB stakeholders priority

\begin{tabular}{|c|c|c|c|c|c|c|c|c|c|}
\hline \multirow{2}{*}{ Stakeholder } & \multicolumn{4}{|c|}{ Attribute score } & \multirow{2}{*}{$\begin{array}{l}\text { Total } \\
\text { score }\end{array}$} & \multirow{2}{*}{$\begin{array}{c}\text { Temporary } \\
\text { priority }\end{array}$} & \multirow{2}{*}{ Position } & \multirow{2}{*}{ Category } & \multirow{2}{*}{$\begin{array}{c}\text { Final } \\
\text { priority }\end{array}$} \\
\hline & $\mathrm{A}$ & $\mathrm{B}$ & $\mathrm{C}$ & $\mathrm{D}$ & & & & & \\
\hline BAPPEDA & 2 & 3 & 3 & 2 & 17 & 2 & Friend & Definitive & 3 \\
\hline Dinas Pariwisata & 2 & 3 & 3 & 2 & 17 & 2 & Friend & Definitive & 2 \\
\hline Dinas Lingkungan Hidup & 2 & 2 & 3 & 2 & 15 & 4 & Friend & Definitive & 8 \\
\hline Kecamatan Tarakan Barat & 3 & 2 & 3 & 1 & 17 & 2 & Friend & Definitive & 4 \\
\hline Kelurahan Karang Rejo & 1 & 1 & 3 & 2 & 10 & 7 & Friend & Discretionary & 12 \\
\hline Universitas Borneo Tarakan & 2 & 3 & 3 & 2 & 17 & 2 & Friend & Definitive & 5 \\
\hline PT Pertamina EP & 3 & 3 & 3 & 1 & 19 & 1 & Friend & Definitive & 1 \\
\hline PT Gusher & 2 & 3 & 3 & 2 & 17 & 2 & Neutral & Definitive & 6 \\
\hline PT Mustika Minanusa Aurora & 2 & 2 & 3 & 3 & 16 & 3 & Friend & Definitive & 7 \\
\hline PT Sabindo Raya Gemilang & 2 & 2 & 3 & 2 & 15 & 4 & Neutral & Definitive & 10 \\
\hline PT Medco EP & 2 & 2 & 3 & 2 & 15 & 4 & Friend & Definitive & 9 \\
\hline Crab fisher & 1 & 2 & 1 & 2 & 10 & 5 & Friend & Demanding & 11 \\
\hline
\end{tabular}

PT Pertamina EP, PT Gusher, PT Mustika Minanusa Aurora, PT Sabindo, and PT Medco EP. Demanding stakeholders in the community depends on KKMB existence without giving a mutual benefit to the area. The community around the natural resources mostly have high interest in the utilization of it, especially about economic and socio-cultural interest (Roslinda et al., 2012). The depending stakeholder of KKMB was crab fisher; this type of stakeholder does not have or has a minimal power towards the area. A discretionary stakeholder is an institution that does not have or has a little urgency towards the area. Discretionary stakeholders of KKMB was Kelurahan Karang Rejo. It was because the existence of KKMB did not have an impact on Kelurahan Karang Rejo. Based on the data collected, PT PLN was categorized as a non-priority stakeholder. It was because PT PLN did not have power, urgency, and legitimacy towards the area. After categorized by its attribute, the score of stakeholders attribute was measured.

Stakeholder priority Priority is the level of need or the right of something to take precedence over the others (Manullang, 2018). The stakeholder that should be prioritized is the organization or institution that its opinion should be preferred on the coordination or decision-taking activity. Stakeholder priority was determined by using the result of Driscoll and Stariks' method of stakeholder analysis. It was because this method was more specific on its attribute scoring (Table 3 ). The attribute score obtained was used as a reference in determining the temporary priority of stakeholder, if there were stakeholders with the same score in the temporary priority, then the priority would be adjusted with stakeholder category and position towards KKMB.

According to the priority table, it was noted that PT Pertamina was the most prioritized stakeholder compared to the other. Despite having the same score, the $2^{\text {nd }}$ priority stakeholder was Dinas Pariwisata, $3^{\text {rd }}$ priority was BAPPEDA, $4^{\text {th }}$ priority was Kecamatan Tarakan Barat, $5^{\text {th }}$ priority was Universitas Borneo, and $6^{\text {th }}$ priority was PT Gusher. This priority was sorted by the consideration that Dinas Pariwisata and BAPPEDA played the role as primary stakeholders that without their involvement, the management of KKMB cannot survive as a going concern. Dinas Pariwisata was more prioritized compared to BAPPEDA because it was the principal manager of KKMB, and it has the coercive power that could affect the area. Kecamatan Tarakan Barat and Universitas Borneo were secondary stakeholders of KKMB, but Kecamatan Tarakan Barat was more prioritized because it has the coercive power (administrative penalty) that could affect KKMB compared to Universitas Borneo. PT Gusher was placed on the $6^{\text {th }}$ priority because it has a neutral position towards KKMB compared to other stakeholders that have the same priority score.

The $8^{\text {th }}$ to $10^{\text {th }}$ stakeholders' priority was determined by the same consideration as the previous priority, stakeholders that have the same priority score used the consideration of the stakeholder status and position towards KKMB. Despite having the same score, Dinas Lingkungan Hidup was more prioritized compared to PT Medco EP and PT Sabindo, it was because this institution had a better understanding to manage KKMB as a mangrove conservation area. Crab fisher was placed on the $11^{\text {th }}$ priority above Kelurahan Karang Rejo with the consideration of its category as a demanding stakeholder, which did not have power but had an urgency towards KKMB. Kelurahan Karang Rejo was placed on the $12^{\text {nd }}$ priority with the consideration of its category as a discretionary stakeholder, which just had legitimacy and did not have power and urgency towards KKMB. PT PLN was not concluded on the priority list with the consideration of its category as a non-priority stakeholder based on the data collected.

Stakeholder management strategy Freeman \& Mc.Vea (1984) mentions five strategies that could be implemented on stakeholder management, i.e., narrow stakeholder, shareholder, utilitarian, Rawlsian, and social harmony strategy. The partnership relation between KKMB and its stakeholders could be improved by implementing the utilitarian strategy. The utilitarian strategy is an effort to optimize the benefit for all stakeholders, to optimize the prosperity rate of all stakeholders, and to optimize the benefit for a wider community (Manullang, 2018). This strategy was the solution to solve KKMB problem, which was partnership relations that are still weak. The utilitarian strategy was 
expected to rebuild the trust among stakeholders to collaborate with KKMB, and it could have happened if the main manager of KKMB tries to meet the stakeholders' needs for $\mathrm{KKMB}$

Meeting the needs of stakeholders for KKMB was important for the strategy so that it needed to understand the needs of KKMB stakeholders. This research shows that almost all of the stakeholders required KKMB to improve the facility maintenance and the cleanliness of the area, besides improving the area sustainability and optimizing its tourism activity. According to Dinas Pariwisata, the needs of area sustainability improvement could be done by returning the KKMB main management to Dinas Lingkungan Hidup because Dinas Lingkungan Hidup has a better understanding on how to manage the ecological and environmental function of KKMB. Most of the stakeholders needed KKMB to optimize its tourism activity so that it could be main tourism attraction of Tarakan, and it could employ more local labors in the future. The efforts to fulfill those needs could be done by collaborating with each of the stakeholders, this thing was intended to improve the role of all stakeholders in the relations with KKMB.

Methods comparison Manullang (2018) states that the use of Driscoll and Stariks' methods on stakeholder analysis has few advantages compared to Reeds' et al. method. The advantages of Driscoll and Starik are the more numbers of the attribute, more numbers of category, ability to identify dangerous stakeholders, more detail information, and more numbers of stakeholder priority levels compared to the Reed et al. method. Reed et al. method is a matrix-plot analysis was then used to examine the interest and influence of stakeholders on the management activities. Then, scales from plot analysis were divided into four quadrants of stakeholders' interest and influence (Bryson et al., 2011). The use of Reed et al. methods is more suitable for an analysis that does not need the component of urgency and legitimacy, and this method is also more suitable to use if there are just fewer stakeholders that are being analyzed, and also there is no threat that may arise from the stakeholders. The Driscoll and Starik methods resulted in more detail stakeholder analysis because of the complexity of the component analyzed. This method is more suitable to be used if there is suspected to be threat from the stakeholder on a project or in an area that is being observed, KKMB in this case.

\section{Conclusion}

KKMB had 13 stakeholders that interacted with each other in a coercive, incentive, and disincentive relationship. PT Pertamina EP was the main stakeholder that needed to be prioritized in coordination and decision-making activities, KKMB manager also needed to strive for fulfilling their needs. The resource conflict of crab fisher and KKMB could be solved by arranging a community empowerment program collaborated with PT Medco that had a similar program in another area of Tarakan. Partnership relations of KKMB with its stakeholders could be improved by applying the utilitarian strategy to optimize the benefit for all stakeholders and community, also to fulfill the stakeholders' needs of KKMB.

\section{Recommendation}

The management of KKMB was recommended to be returned to Dinas Lingkungan Hidup Kota Tarakan so that it can be more focus on the management of the ecological and environmental function of KKMB. The main manager of KKMB needed to coordinate with all of the stakeholders to improve their partnership relations.

\section{References}

Bungin, B. (2010). Penelitian kualitatif. Jakarta: Kencana Prenada Media Grup.

Bryson, J. M., Patton, M. Q., \& Bowman, R. A. (2011). Working with evaluation stakeholders: A rationale, stepwise approach. Evaluation and Program Planning, 34, 1-12. https://doi.org/10.1016/j.evalprogplan.2010. 07.001

Clarkson, M. B. E. (1995). A stakeholder framework for analyzing and evaluating corporate social performance. The Academy of Management Review, 20, 92-117. tps://doi.org/10.5465/amr.1995.9503271994

Driscoll, C., \& Starik, M. (2004). The primordial stakeholder: Advancing the conceptual consideration of stakeholder status for the natural environment. Journal of Business Ethics, 49, 55-73. https://doi.org/10.1023/ B:BUSI.0000013852.62017.0e

Febriyano, I. G. (2014). Politik ekologi pengelolaan mangrove di Kabupaten Pesawaran Provinsi Lampung [dissertation]. Bogor: Bogor Agricultural University

Freeman, R. E., \& McVea, J. (1984). A stakeholder approach to strategic management. Charlottesville: University of Virginia Press.

Galbraith, J. K. (1983). The anatomy of power. Boston: Houghton Mifflin. https://doi.org/10.1080/05775132. 1983.11470852

Krott, M., Bader, A., Schusser, C., Devkota, R., Maryudi, A., Giessen, L., \& Aurenhammer, H. (2014). Actor-centred power: The driving force in decentralised community based forest governance. Forest Policy and Economics, 49, 34-42. https://doi.org/10.1016/j.forpol.2013.04.012

Maguire B, Potss J, Fletcher S. 2012. The role of stakeholders in themarine planning process-stakeholder analysis within the Solent, United Kingdom. Marine Policy 36, 246-257.https://doi.org/10.1016/j.marpol.2011.05.012

Manullang, S. (2018). Teori dan teknik analisis stakeholder: Untuk manajemen proyek, organisasi, bisnis, kajian isu/kebijakan, politik, dan keseharian anda. Bogor: IPB Press.

Mitchell, R. K., Agle, B. R., \& Wood, D. J. (1997). Toward a theory of stakeholder identification and salience: Defining the principle of who and what really counts. The 
Academy of Management Review, 22, 853-886. https://doi.org/10.5465/amr.1997.9711022105

Parent, M. M., \& Deephouse, D. L. (2007). A case study of stakeholder identification and prioritization by managers. Journal of Business Ethics, 75, 1-23. https://doi.org/10.1007/s10551-007-9533-y

Reed, M., Graves, A., Dandy, N., Posthumus, H., Hubacek, K., Morris, J., ... Stringer, L. C. (2009). Who's and why? A typology of stakeholder analysis methods for natural resource management. Journal of Environmental Management, 90, 1933-1949. https://doi.org/10. 1016/j.jenvman.2009.01.001

Roslinda, E., Darusman D., Suharjito, D., \& Nurrochmat, D.
R. (2012). Stakeholders analysis on the management of Danau Sentarum National Park Kapuas Hulu Regency, West Kalimantan. Jurnal Manajemen Hutan Tropika, 2, 78-85. https://doi.org/10.7226/jtfm.18.2.78

Syahputra, O. K. H., Nugroho, B., Kartodihardjo, H., \& Santoso, N. (2018). Stakeholder analysis in community based mangrove management: Case of forest management unit in Region 3 of Aceh Province. Jurnal Manajemen Hutan Tropika, 24, 152-161. https://doi.org/10.7226/jtfm.24.3.156

Wiharyanto, D. (2007). Kajian pengembangan ekowisata mangrove di Kawasan Konservasi Pelabuhan Tengkayu II Kota Tarakan Kalimantan Timur. [thesis]. Bogor: IPB University. 